\title{
Circulating Tumour Cells in Predictive Molecular Pathology: Focus on Drug-Sensitive Assays and 3D Culture
}

\author{
Pierlorenzo Pallante ${ }^{a}$ Pasquale Pisapia ${ }^{b}$ Claudio Bellevicine ${ }^{b}$ \\ Umberto Malapelle $^{b}$ Giancarlo Troncone ${ }^{b}$ \\ anstitute of Experimental Endocrinology and Oncology (IEOS) "G. Salvatore," National Research Council (CNR),

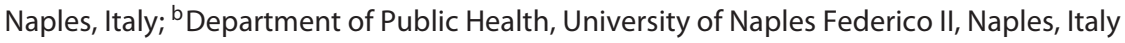

\section{Keywords}

Liquid biopsy · Circulating tumour cells · Solid tumour · 3D culture

\begin{abstract}
Molecular cytopathology is a rapidly evolving field of cytopathology that provides biological information about the response to personalised therapy and about the prognosis of neoplasms diagnosed on cytological samples. Biomarkers such as circulating tumour cells and circulating tumour DNA are increasingly being evaluated in blood and in other body fluids. Such liquid biopsies are non-invasive, repeatable, and feasible also in patients with severe comorbidities. However, liquid biopsy may be challenging due to a low concentration of biomarkers. In such cases, biomarkers can be detected with highly sensitive molecular techniques, which in turn should be validated and integrated in a complex algorithm that includes tissue-based molecular assessments. The aim of this review is to provide the cytopathologist with practical information that is relevant to daily practice, particularly regarding the emerging role of circulating tumour cells in the field of predictive molecular pathology.
\end{abstract}

๑) 2019 S. Karger AG, Basel

\section{Introduction}

Molecular cytopathology is a rapidly evolving field of cytopathology based on cytology and "omics" technologies [1]. The recent advent of targeted treatment for many advanced solid tumours led to the widespread implementation of biomarker testing to select cancer patients potentially sensitive to these treatments $[2,3]$. Tissue specimens are now considered the gold standard for molecular analysis. Core-needle biopsy and fine-needle aspiration (FNA) procedures are used to sample superficial and deep-seated lesions [4-8]. FNA has several advantages over core-needle biopsy: (1) FNA can sample a larger area of the lesion; (2) FNA samples tumour cells that are less contaminated by stromal tissue, and (3) because FNA enables on-site adequacy assessments, the preliminary diagnosis can be immediately conveyed to clinical care providers [9]. However, the amount of tumour tissue sampled by FNA may not be sufficient for molecular testing, whereas the number of biomarkers to test in such solid tumours as non-small cell lung cancer (NSCLC) and colorectal cancer (CRC) is steadily increasing. Further-

Dr. Malapelle and Dr. Troncone contributed equally to this article. 
Fig. 1. Schematic representation of CTC morphological evaluation and molecular analysis. (A) Cytopathologists play an important role in the morphological identification of CTCs from other non-neoplastic cells, with classical microscopic evaluation. CTC analysis allows information to be obtained regarding gene expression profiling assessment (B) and mutational analysis (C - circle plot for an exemplificative exome analysis) and protein expression (D), in order to obtain relevant information in predictive and prognostic settings.

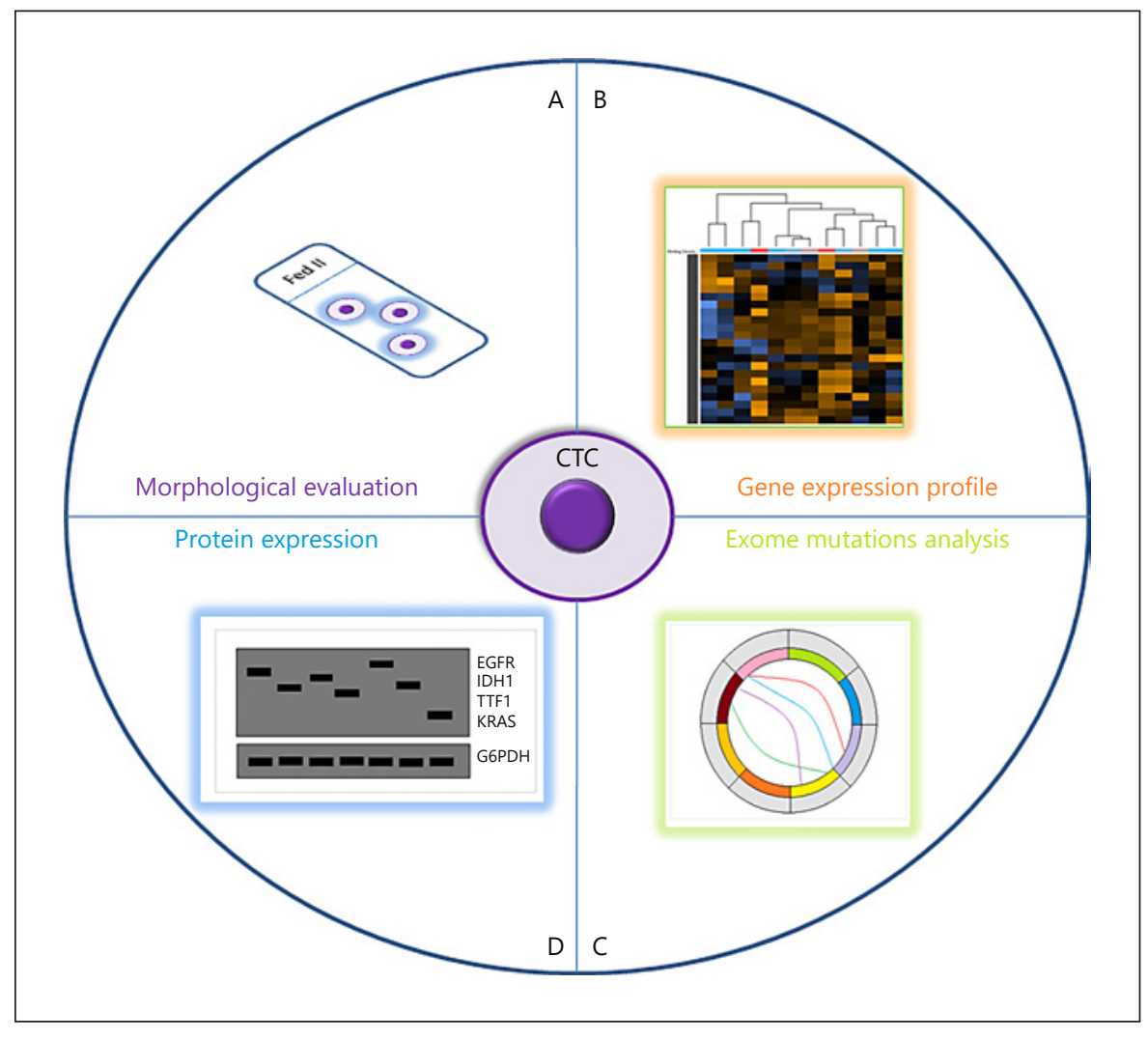

more, treatment may alter the mutational status of tumours, which implies the need for serial samplings [10, 11]. However, re-biopsy after initial treatment is not always feasible in patients with comorbidity [11]. With the introduction of second-line targeted treatment with the EGFR tyrosine kinase inhibitor osimertinib in T790Mpositive NSCLC patients, blood became an easily accessible source of biological material because, for the first time, a patient's mutational status could be defined and dynamically monitored [12].

In the field of predictive molecular pathology, the analysis of biological components in blood and other body fluids is referred to as "liquid biopsy" [11, 13-15]. From a clinical point of view, liquid biopsy is a non-invasive repeatable procedure that can be performed also in patients with severe comorbidities [13-15]. Circulating tumour cells (CTCs) and circulating tumour DNA can be detected in whole blood, plasma, and serum [15-17]. However, given the very low concentration of CTCs, highly sensitive techniques are required for their analysis, and these in turn should be validated and integrated in a complex algorithm that includes tissue-based molecular assessments (Fig. 1) [18-20]. Consequently, liquid biop- sy-based techniques represented a breakthrough in this setting [11, 13].

The aim of this review is to give the cytopathologist practical information regarding the liquid biopsy technique that is relevant to daily practice, and to illustrate the emerging role of CTCs in the field of predictive molecular pathology (Fig. 2).

\section{Circulating Tumour Cells}

From the earliest phases of tumour development, neoplastic cells, including CTCs, are actively shed into the bloodstream through the epithelial-to-mesenchymal transition (EMT) [21, 22]. The expression of EMT markers is associated with enhanced CTC invasion and migration as well as enhanced resistance to apoptosis and necrosis [23]. These cells can remain dormant for several years in specific "niches" (e.g., bone marrow) before giving rise to overt metastases $[18,24]$. CTCs with an intermediate epithelial-mesenchymal phenotype, which is characterised by low expression of the epithelial cell adhesion molecule (EpCAM), and high expression of tyro- 


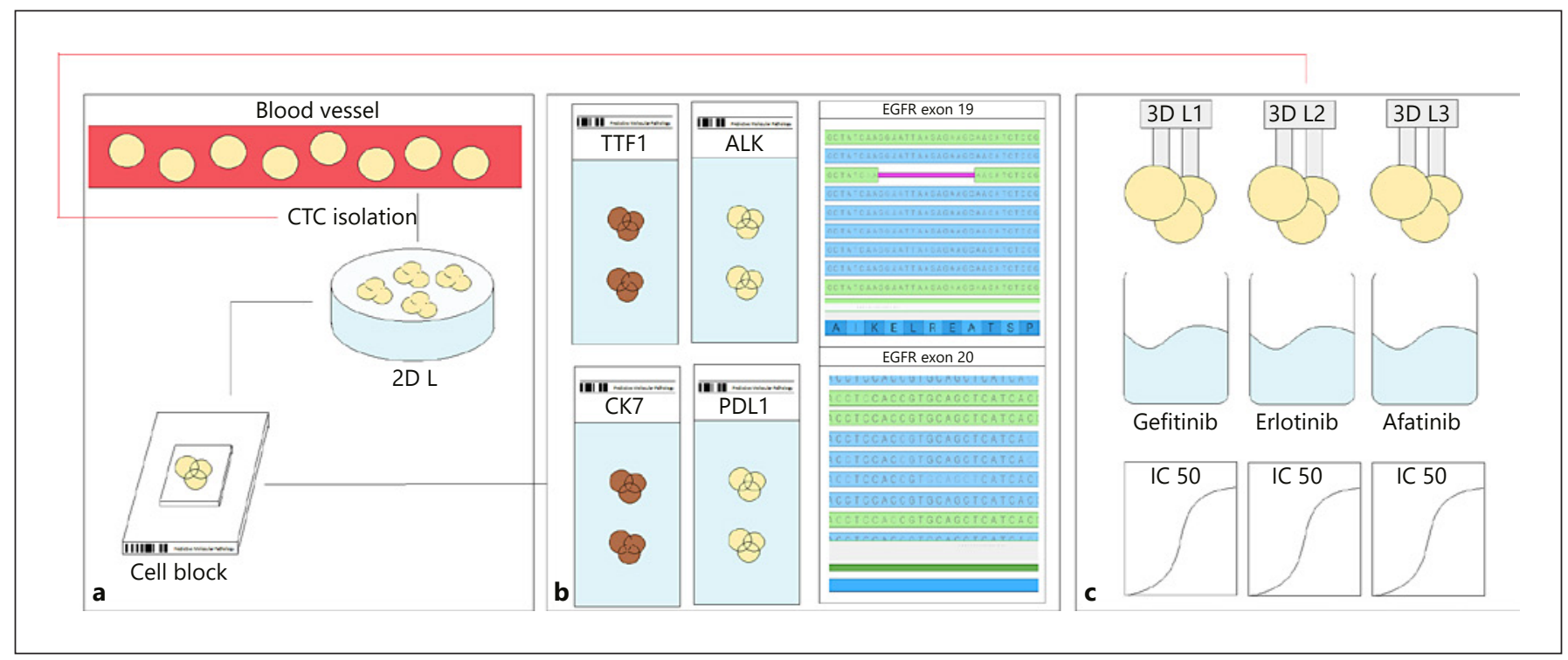

Fig. 2. $2 \mathrm{D}$ and $3 \mathrm{D}$ culture applications. a CTCs isolated from blood samples were cultured in monolayer (2D) and prepared as a cell block. b Serial sections derived from the cell block were used for phenotypic (TTF-1, CK7, ALK, PD-L1) and molecular characterisation, identifying an EGFR exon 19 deletion (p.E746_A750delELREA). c 3D cultures prepared starting from isolated CTCs with EGFR exon 19 deletion were tested for IC50 assay using three EGFR tyrosine kinase inhibitors (gefitinib, erlotinib, and afatinib).

sine-protein kinase, Met, are very aggressive and able to metastasise [18, 25-28]. EpCAM is a protein exclusively expressed by epithelia and neoplasms of epithelial origin and are therefore used to select CTCs [25]. CTCs can also derive from neoplastic microemboli $[29,30]$. The latter are composed of at least two tumour cells and, occasionally, by normal blood cells [19]. The formation of microemboli results from the increased adhesive capacity of CTCs, and improves the metastatic potential of these cells. Notably, CTCs elude the immune system through many immune checkpoint inhibitor systems such as programmed cell death protein 1 and programmed deathligand $1[31,32]$.

The generally low concentration of CTCs in peripheral blood (usually $1-10$ cells per $10 \mathrm{~mL}$ ) and their halflife makes it difficult to distinguish CTCs from normal blood cells [19]. One strategy with which to distinguish between the two cell types is to analyse markers expressed by tumour cells (e.g., cytokeratin and EpCAM) but not by normal blood cells $[18,19]$. However, false negative results can derive from the downregulation of epithelial markers that occurs during the EMT $[18,33]$. The novel marker actin bundling protein plastin 3 is not downregulated during the EMT of CTCs and is not expressed in blood cells, and can thus overcome this problem $[18,34]$.
Other important issues remain to be addressed, namely false positive results due to artefacts and to the presence of CTCs in benign diseases (e.g., Crohn disease and diverticulosis) $[18,35]$.

Studies conducted in mouse models show that CTCs can serve as biomarkers for early solid tumours. For example, in a mouse model of pancreatic tumour, cancer cells were found in the bloodstream before any primary tumour was detectable $[36,37]$. Moreover, particular molecular signatures can also predict the site of CTC metastases. For instance, in mouse xenograft experiments, EpCAM-negative CTCs in brain metastatic breast cancer were found to be characterised by the expression of selected markers (HER2+/EGFR+/HPSE+/NOTCH1+) that render these cells prone to generate brain metastases [38].

The analysis of CTCs can help to shed light on tumour cell dissemination and help to improve the management of metastatic disease [39]. In fact, DTCs (disseminated tumour cells) were included in the 2010 edition of the AJCC TNM (tumour-node-metastasis) cancer staging manual as $\mathrm{cM}_{0}(\mathrm{i}+)$ classification [19]. In addition, targeting the dormant DTCs resident in niches like bone marrow can reduce the probability of metastases [24]. Although the clinical significance of CTCs is still debated [19], growing evidence indicates that the presence of 
CTCs in the bloodstream of cancer patients is an important prognostic factor and is predictive of the response to therapy [19]. The measurement of CTCs has not been included in clinical guidelines because their clinical utility is unclear, and they have yet to be validated in a prospective randomised clinical trial [19]. CTCs play a relevant role in small cell lung cancer (SCLC). In particular, CTCs were detectable in about $70-95 \%$ of patients with SCLC $[40,41]$. The identification of CTCs may play an important role in the early detection of SCLC [40]. In the experience by Ilie et al. [42], the authors showed that all patients with the identification of CTCs developed a pulmonary nodule during the follow-up and before CT identification. A high level of CTCs in SCLC patients correlates with the worst prognosis [40]. In a study by Hou et al. [43], a high number of CTCs $(>300)$ was associated with a significant reduction of survival compared to patients with a low number of CTCs detected $(<2)$. Another important role of CTCs in these patients was represented by the possibility of a molecular characterisation of CTCs that can provide relevant clinical information [40]. Pore et al. [44] demonstrated the possibility that there was a relationship between the number of CTCs and overall survival rate, correlated to the presence of cancer stem cell (CSC) markers and mesenchymal markers in tumour biopsy samples.

\section{CTC Selection}

Various techniques have been devised to identify and isolate CTCs [18, 19, 45, 46]. The US Food and Drug Administration (FDA) approved the Cell-Search assay (Janssen Diagnostic, Raritan, NJ, USA) only for the enumeration of CTCs in breast and prostate cancer and CRC [33, $46,47]$. This assay is a protein expression-based technology by which CTCs are captured by immunomagnetic beads thanks to the expression of EpCAM on their cell surface $[19,20,48,49]$. The advantage of this method is that EpCAM is not expressed on the surface of non-neoplastic circulating cells, while the principal disadvantage is the possibility of low EpCAM expression during the EMT. Other markers are being evaluated to address this problem [18, 19, 49-53].

Other techniques are available to detect and isolate CTCs although they do not have FDA approval $[18,19$, 54-58]. For example, being larger and less prone to deform than hematopoietic cells, CTCs can be isolated by devices based on cell filtration and centrifugation $[18,19$, 59]. In addition, functional assays, like the EPISPOT as- say, are based on the detection of specific proteins secreted during in vitro culture of CTCs [18-20,60]. Besides not having FDA approval, the use of these assays in the era of multimarker assessment is much debated [18, 19]. The DEPArray ${ }^{\mathrm{TM}}$ system (Silicon Biosystems, Bologna, Italy) is a technology based on a semiautomated system that allows the isolation of CTCs, with the capacity to generate a non-uniform electric field with the ability to develop an attractive force on polarisable elements (such as cells) that are suspended in a liquid [61, 62]. This principle is called dielectrophoresis (DEP) and allows fluorescently labelled CTCs to be isolated using a chip in which different microelectrodes create electric cages for the CTCs [61, 62]. Important advantages of this technique are that it allows individual cells to be trapped, manipulated, and recovered, with the activation and deactivation of the microelectrodes; it allows the identification of multiple cells and cell types in a sample; it does not create particular damage on cells due to the low voltage adopted $[61,62]$. In a study by Paolillo et al. [63], the authors adopted the DEPArray ${ }^{\mathrm{TM}}$ system in breast cancer liquid biopsy samples and the analysis of ESR1 (oestrogen receptor 1) mutation was correctly performed on all single cells isolated.

\section{CTCs and Conventional Cytology}

As a general rule, cytomorphological features can be used to increase the specificity of CTCs provided the integrity of the cells is well preserved [20,64]. The isolation by size of epithelial tumour cells (ISET) technique complements standard cytopathology well [65]. The ISET method, based on the larger size of CTCs versus hematopoietic cells, has the advantage of highly sensitive enrichment while preserving cell integrity [65]. In a study by Hofman et al. [66], $10 \mathrm{~mL}$ of peripheral blood from 208 lung cancer patients were collected in buffered EDTA before surgical resection, and processed by the ISET technique. Using a modified May-Grünwald-Giemsa method to stain CTCs, they identified the microscopic features of malignancy in 102 of these patients. The agreement within a panel of 10 cytopathologists was excellent. In fact, in all 102 cases, at least 5/10 cytopathologists agreed on the classification of CTCs in three categories (CTCs with malignant features, with uncertain malignant features, and with benign features) using the following cytological criteria: irregularity and size of nucleus, anisonucleosis, nuclear hyperchromatism, nucleocytoplasmic ratio, size and number of nucleoli, and the presence of tridimensional 
sheets. In addition, using a semiquantitative analysis, the cytopathologists defined three groups: group 1 with less than 10 CTCs, group 2 with between 10 and 100 CTCs, and group 3 with more than 100 CTCs. Notably, the morphological features of circulating non-hematologic cells did not distinguish among the different histological subtypes. The presence of a preoperative high level of circulating non-hematologic cells was associated with a worse outcome for resectable lung cancer patients [66].

CTCs can also be visualised with such cytological methods as cytospin, ThinPrep, and cell block. Both the two principal cytological staining procedures, Romanowski and Papanicolaou, are performed on slides to visualise CTCs. Immunocytochemistry can also be used to detect diagnostic biomarkers [67].

\section{Ex vivo Culture of CTCs and Chemosensitivity Assays}

The choice of the most effective chemotherapy protocol after the eradication of the primary tumour mass is based on TNM staging and on the results of clinical trials. The identification of CTCs can help to improve personalised medicine for cancer patients. In fact, CTCs can be used to perform sensitivity assays to test the efficacy of such treatments in each patient $[68,69]$. Moreover, CTCs detach from the primary mass and generate metastases, thereby overcoming the molecular heterogeneity of the tumour mass [68-70].

CTCs can be used in predictive in vitro tests in individual patients. Indeed, the treatment response rate obtained with the CTC model was found to be closely associated with the response observed in the patient in vivo immediately after surgical removal of the tumour, and in metastatic patients [71-73]. Therefore, CTCs can also be used to evaluate the response to treatment during the different phases of the disease, and treatment can be adjusted according to the evolution of the disease. In this context, Rüdiger et al. [72] demonstrated that the evaluation of chemosensitivity of CTCs and white cells comprising the circulating epithelial tumour cells (CETCs) in vitro is associated with the success of therapy in vivo and that it provides early information about the response to therapy.

In a recent ground-breaking study, in vitro drug sensitivity assays were performed in breast cancer patients with metastatic luminal oestrogen-positive breast cancers using ex vivo CTCs [74]. The authors generated at least one cell culture from 6 of 36 patients off therapy or progressing on treatment, but no cell culture lines from 9 patients responding to treatment [74]. Besides demon- strating that CTCs in culture shared most of the characteristics of CTCs directly isolated from blood, they also identified additional features. In particular, they found acquired mutations in the ESR 1 and phosphatidylinositol 4,5-bisphosphate 3-kinase catalytic subunit alpha isoform (PIK3CA) genes on CTCs in culture that were not present in the primary tumours [74]. Thanks to genotyping assessment, it is possible to evaluate the response to a given treatment based on the stratification of patients according to the mutations found [74].

CTCs extracted and expanded from CRC patients are a useful model for drug sensitivity testing in the framework of personalised medicine [75]. Grillet et al. [75] obtained three different CTC cell lines starting from four chemotherapy-naïve patients with metastatic CRC (stage IV). They were not able to obtain any CTC line from patients with lower stage (stage I/II, 0/9; stage III, 0/6) or chemotherapy-treated CRC patients (stage IV, 0/13; stage I/II, 0/3). They expanded cells and performed assays in less than 1 month [75], which is a critical point when CTC drug assays are performed to decide treatment. They found that the different cells lines responded differently to treatment with combinations of fluorouracil and irinotecan, and multikinase inhibitor regorafenib and vemurafenib. Once again, this is an important point since the results of in vitro tests can guide the oncologist's choice regarding the best chemotherapeutic cocktail also in the attempt to avoid adverse side effects [75].

Drug sensitivity assays seem to be very promising in the field of breast cancer where it is often necessary to perform several biopsies to monitor the evolution of the malignancy, particularly in terms of the status of the oestrogen receptor and HER2 (human epidermal growth factor receptor 2) [74]. CTCs isolated from blood samples are useful in this context because the procedure is noninvasive and the cells can be used for genetic evaluation and drug sensitivity assays [76]. Notably, CTCs are currently being evaluated in clinical trials of breast cancer patients in the attempt to predict the response of patients to treatment with HER-targeted therapy [76-79].

\section{Chemosensitivity Assays Using Blood Samples}

In 2014, Hughes et al. [80] reported a method to test the response to treatment in which chemotherapy compounds are added to the tube containing the blood sample, and then, after a well-defined time lapse, the CTCs present in the blood sample are counted. They found that response to treatment with docetaxel, doxorubicin, and 
mitoxantrone differed among blood samples obtained from 7 cancer patients ( 3 breast cancer, 2 prostate, 1 renal, and 1 colon). This test is rapid and simple and can be applied to different CTC isolation platforms. However, as acknowledged by the authors, a lower number of CTCs recovered after treatment may not always accurately reflect therapeutic efficacy [80]. Many clinical trials are now monitoring the CTC count during treatment of various cohorts of patients to verify whether CTC count is a valid predictive tool of response or relapse $[78,81]$. In addition, testing CTC sensitivity to compounds in their natural medium (blood) could be another variable to use in the context of CTC testing in predictive medicine.

\section{Three-Dimensional Cell Culture Models}

In recent decades, the development of three-dimensional (3D) cell cultures has given an impulse to cancer research. In fact, the cells in the body work by interacting with the surrounding cells and with the extracellular matrix [82-84]. Therefore, 3D models of cell cultures can be used to study proliferation, differentiation, apoptosis, migration, and invasion [85, 86]. Even more important is their use in studies of cytotoxicity and sensitivity to treatment since cells in $3 \mathrm{D}$ cultures are much more resistant to chemotherapy and radiotherapy versus traditional monolayer cultures (2D) [83, 85, 87-89]. This explains why compounds that pass the first screening on cell culture in vitro are subsequently discarded due to their inefficacy on 3D cell models including CTC and animal models.

Three 3D cell culture models have been generated so far: (i) 3D spheroids $[90,91]$; (ii) cultures in which natural and synthetic hydrogels and extracellular matrices serve as platforms, $[92,93]$ and (iii) cultures on solid scaffolds [94]. These models are applied in various settings, such as the differentiation of stem cells, the generation of organoids, studies of the biology of cancer cells, in multicellular models of cocultures, and finally, in generating organs on chips for drug discovery and toxicity studies $[90,92,93]$.

\section{Application of CTCs in 3D Cultures}

3D cell cultures can be generated starting from tissues or cell lines, and a particularly promising application, although in its infancy, is in the field of CTCs. Obviously, such an application involves the use of particular expedients such as eliminating blood cells and cellular contaminants [74]. In fact, CTCs derived from breast cancer can proliferate as tumorspheres [74]. Although the tumorsphere model does not completely recapitulate the $3 \mathrm{D}$ architecture and biology of the tumour, it is useful for studies of stem cell differentiation [95]. In addition, CTCs obtained from the blood of breast cancer patients constitute an excellent tool with which to study drug susceptibility in relation to the unique genetic context of each individual tumour in the desirable perspective of personalised therapy [74].

It is difficult to obtain viable CTCs and many cells die during the purification procedure [45]. In their 2014 report, Yu et al. [74] used the CTC-iCHIP technology to purify and expand CTCs obtained from patients with oestrogen receptor-positive metastatic breast cancer. This result shows that such studies can be performed in patients who, being metastatic, cannot be biopsied [74].

The ability of CTCs to grow as $3 \mathrm{D}$ spheroids may directly depend on their tendency to remain viable in the bloodstream despite not being adhered to the extracellular matrix [74]. Bichsel et al. [96] showed that a microfluidic chip could be used as a culture chamber in $3 \mathrm{D}$ on the hydrogel matrix for prostate CTCs. Indeed, the captured cells do not detach from the support, and consequently are not lost, so that the CTCs can be expanded in a clonal and $3 \mathrm{D}$ fashion within the same support $[96,97]$. The spheroids thus obtained can be used as models since they are sufficiently similar to the tumours from which they derive (expression of surface markers, response to drugs, cellular heterogeneity, stem properties) [98-100], and so provide information about disease progression [96]. Moreover, these cells are clonogenic in vitro and can reform the tumour when injected in vivo [96, 101-103]; these characteristics are almost certainly due to the maintenance of some stem-like properties [104, 105].

CTCs act as precursors of metastases, but their role in this process has only recently been clarified, mainly because CTCs are rare and it is often difficult to obtain an adequate number [106]. In fact, previously, CTCs were mostly isolated and amplified from animal models or from patients in advanced stages of disease [38, 74, 107]. However, a recent study showed that CTCs of early-stage lung cancer can be captured directly using a microfluidic chip by adding tumour-associated fibroblasts and the extracellular matrix in coculture to the 3D scaffold [106]. Thus, the optimal cellular microenvironment, where rare CTCs can be amplified and used for subsequent studies of invasion, the formation of spheroids, and gene sequencing, is recreated [106].

Another possible application of CTCs in 3D cultures in studies of the metastatic process was reported in a recent 


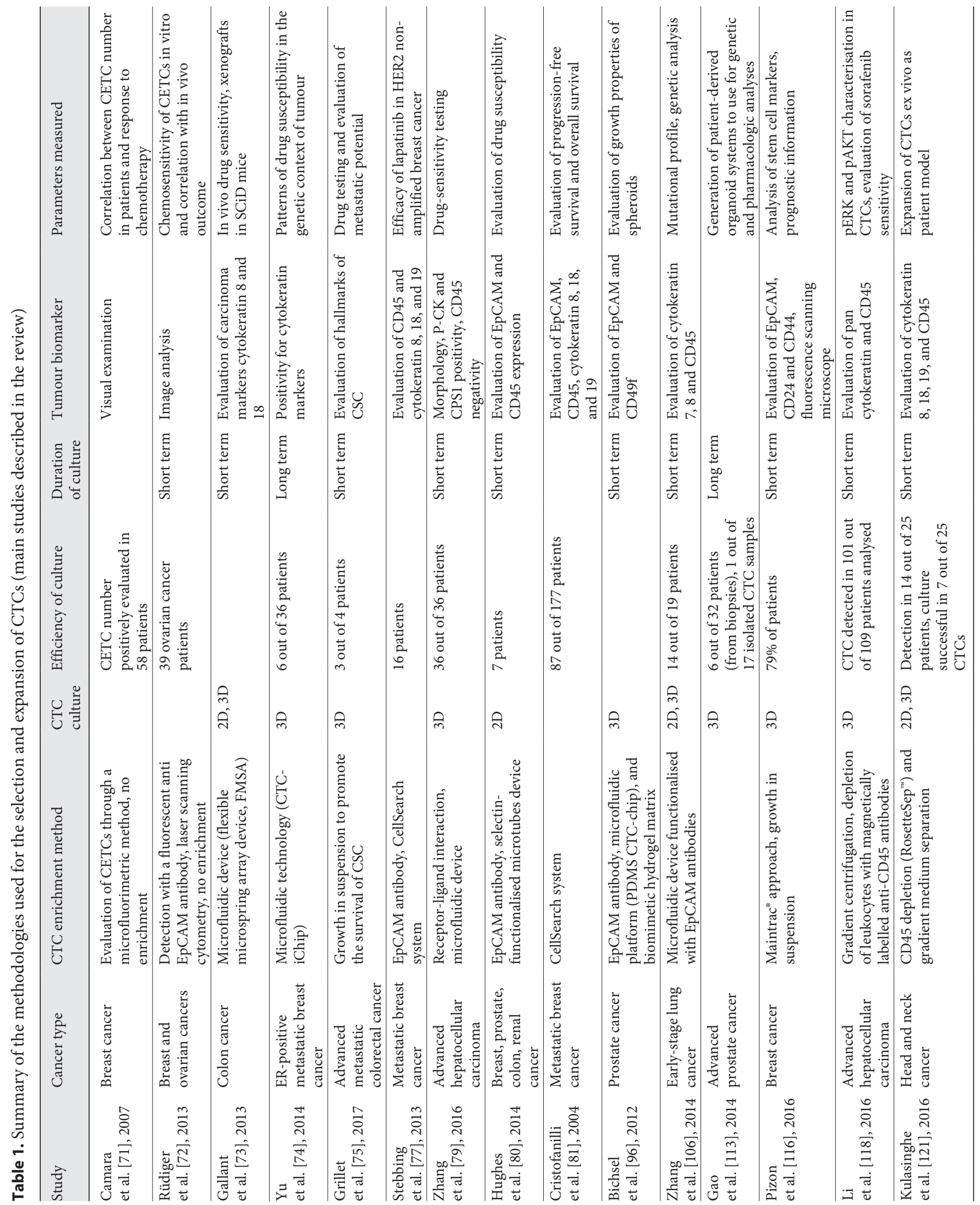


review [108]. Namely, it appears that the interaction between CTCs and the endothelial cells of vessels is modulated by mechanical factors such as blood flow $[109,110]$. In addition, it has been seen that this interaction also depends on the physiological state of endothelial cells [111, 112]. These interactions can be studied, at least in principle, using appropriate $3 \mathrm{D}$ models that rebuild the interaction between cells within a microfluidic device [108].

Gao et al. [113] confirmed that organoids can be generated from CTCs obtained from patients with metastatic prostate cancer. They also showed that the organoid cell line can be long-term propagated. Thus, the results of molecular and genomic characterisation studies recapitulate the characteristics of the primary tumour [113]. Even more interesting is the possibility of genetically manipulating the organoid to study the response to treatment $[113,114]$. In fact, gene transfer and gene targeting can be performed in liver and pancreas organoids using viral vectors (retrovirus, lentivirus, and adenovirus) and the CRISPR/Cas system, respectively [115].

Pizon et al. [116] recently reported that tumorspheres can be obtained starting from breast cancer CTCs. They selected a particular subpopulation of CTCs with stem cell characteristics using a specific culture medium and, intriguingly, showed that the number of tumorspheres obtained depends on the chemotherapeutic regimen to which the patient is subjected [116]. Thus, the CSC fraction of a CTC population can be monitored. The novelty of the study by Pizon et al. [116] is the use of the 3D growth of CTC to enrich the aggressive and probably metastases-generating CSC population [51, 116, 117]. This experimental method for the enrichment of circulating CSCs is well established in cultured cell lines and cells obtained by disrupting the primary tumour.

Li et al. [118], used CTCs from patients suffering from hepatocellular carcinoma to obtain the cellular subpopulations based on the different levels of pERK and pAKT to monitor the response to sorafenib in relation to the levels of phosphoproteins. They used a 3D model of spheroids $[118,119]$ to track the sensitivity and progression-free survival in all patients. This is another example of personalised therapy.

\section{Perspectives on the Use of CTCs in 3D Cell Cultures}

Given the widespread use of CTCs and liquid biopsy in recent years, mainly as a consequence of their noninvasive nature, it is feasible that their applications will increase in the fields of personalised medicine and the

biology of metastases [120]. A series of applications in 3D cultures that best mimic the characteristics of the primary starting tumour have already been reported $[82,84-$ 86]. It has also been reported that CTCs grow for a longer time in 3D conditions than in 2D conditions [121].

A pioneering application of CTCs was reported by Mishra et al. [122] in 2015 in lung cancer. They used a 4D model (3D with liquid flow) of acellular rat lung, in which cells of interest were left to colonise the matrix, then examined the characteristics of nodules that appeared. They found that cells in $4 \mathrm{D}$ culture are more aggressive and release the CTCs responsible for the metastasis [122].

In conclusion, 3D cultures more closely resemble animal models than do 2D cultures, and can be used to study the complex interactions that occur within the body [123]. Their applications in basic and applied research are numerous and include drug discovery, cell physiology, tissue engineering, pharmacology, cancer research, and gene expression [123] (Table 1). Specifically, it seems that the amplification of rare CTCs is more efficient with the $3 \mathrm{D}$ cell culture models than with $2 \mathrm{D}$ models. In addition, they can also be used to study metastases and the processes of malignancy because growth experiments can be performed without anchorage to the substrate. Lastly, the response to treatment can be studied using CTCs in 3D models, thereby improving personalised medicine.

\section{Acknowledgements}

The authors thank Jean Ann Gilder (Scientific Communication srl., Naples, Italy) for writing assistance.

\section{Disclosure Statement}

The authors have no conflicts of interest to disclose.

References

Acta Cytologica 2019;63:171-181 DOI: $10.1159 / 000496213$
Pallante/Pisapia/Bellevicine/Malapelle/ Troncone
1 Vigliar E, Malapelle U, de Luca C, Bellevicine C, Troncone G. Challenges and opportunities of next-generation sequencing: a cytopathologist's perspective. Cytopathology. 2015 Oct; 26(5):271-83.

2 Scott AM, Wolchok JD, Old LJ. Antibody therapy of cancer. Nat Rev Cancer. 2012 Mar; 12(4):278-87.

3 Hoelder S, Clarke PA, Workman P. Discovery of small molecule cancer drugs: successes, challenges and opportunities. Mol Oncol. 2012 Apr;6(2):155-76. 
4 Bellevicine C, Vita GD, Malapelle U, Troncone G. Applications and limitations of oncogene mutation testing in clinical cytopathology. Semin Diagn Pathol. 2013 Nov;30(4): 284-97.

5 Roy-Chowdhuri S, Aisner DL, Allen TC, Beasley MB, Borczuk A, Cagle PT, et al. Biomarker Testing in Lung Carcinoma Cytology Specimens: A Perspective From Members of the Pulmonary Pathology Society. Arch Pathol Lab Med. 2016 Apr;140(11):1267-72.; Epub ahead of print.

6 Savic S, Tapia C, Grilli B, Rufle A, Bihl MP, de Vito Barascud A, et al. Comprehensive epidermal growth factor receptor gene analysis from cytological specimens of non-small-cell lung cancers. Br J Cancer. 2008 Jan;98(1): $154-60$.

7 Killian JK, Walker RL, Suuriniemi M, Jones L, Scurci S, Singh P, et al. Archival fine-needle aspiration cytopathology (FNAC) samples: untapped resource for clinical molecular profiling. J Mol Diagn. 2010 Nov;12(6):739-45.

8 van Eijk R, Licht J, Schrumpf M, Talebian Yazdi M, Ruano D, Forte GI, et al. Rapid KRAS, EGFR, BRAF and PIK3CA mutation analysis of fine needle aspirates from nonsmall-cell lung cancer using allele-specific qPCR. PLoS One. 2011 Mar;6(3):e17791.

9 Coley SM, Crapanzano JP, Saqi A. FNA, core biopsy, or both for the diagnosis of lung carcinoma: obtaining sufficient tissue for a specific diagnosis and molecular testing. Cancer Cytopathol. 2015 May;123(5):318-26.

10 Bettegowda C, Sausen M, Leary RJ, Kinde I, Wang Y, Agrawal N, et al. Detection of circulating tumor DNA in early- and late-stage human malignancies. Sci Transl Med. 2014 Feb; 6(224):224ra24.

11 Malapelle U, Pisapia P, Rocco D, Smeraglio R, di Spirito M, Bellevicine C, et al. Next generation sequencing techniques in liquid biopsy: focus on non-small cell lung cancer patients. Transl Lung Cancer Res. 2016 Oct;5(5):50510.

12 Chia PL, Do H, Morey A, Mitchell P, Dobrovic A, John T. Temporal changes of EGFR mutations and T790M levels in tumour and plasma DNA following AZD9291 treatment. Lung Cancer. 2016 Aug;98:29-32.

13 Malapelle U, Mayo de-Las-Casas C, Rocco D, Garzon M, Pisapia P, Jordana-Ariza N, et al. Development of a gene panel for next-generation sequencing of clinically relevant mutations in cell-free DNA from cancer patients. Br J Cancer. 2017 Mar;116(6):802-10.

14 Wan JC, Massie C, Garcia-Corbacho J, Mouliere F, Brenton JD, Caldas C, et al. Liquid biopsies come of age: towards implementation of circulating tumour DNA. Nat Rev Cancer. 2017 Apr;17(4):223-38.

15 Crowley E, Di Nicolantonio F, Loupakis F, Bardelli A. Liquid biopsy: monitoring cancergenetics in the blood. Nat Rev Clin Oncol. 2013 Aug;10(8):472-84.
16 Haber DA, Velculescu VE. Blood-based analyses of cancer: circulating tumor cells and circulating tumor DNA. Cancer Discov. 2014 Jun;4(6):650-61.

17 Alix-Panabières C, Pantel K. Clinical Applications of Circulating Tumor Cells and Circulating Tumor DNA as Liquid Biopsy. Cancer Discov. 2016 May;6(5):479-91.

18 Alix-Panabières C, Pantel K. Circulating tumor cells: liquid biopsy of cancer. Clin Chem. 2013 Jan;59(1):110-8.

19 Alix-Panabières C, Pantel K. Challenges in circulating tumour cell research. Nat Rev Cancer. 2014 Sep;14(9):623-31.

20 Hong B, Zu Y. Detecting circulating tumor cells: current challenges and new trends. Theranostics. 2013 Apr;3(6):377-94.

21 Klymkowsky MW, Savagner P. Epithelialmesenchymal transition: a cancer researcher's conceptual friend and foe. Am J Pathol. 2009 May; 174(5):1588-93.

22 Banyard J, Bielenberg DR. The role of EMT and MET in cancer dissemination. Connect Tissue Res. 2015;56(5):403-13.

23 Tsai JH, Yang J. Epithelial-mesenchymal plasticity in carcinoma metastasis. Genes Dev. 2013 Oct;27(20):2192-206.

24 Ghajar CM. Metastasis prevention by targeting the dormant niche. Nat Rev Cancer. 2015 Apr;15(4):238-47.

25 Rao CG, Chianese D, Doyle GV, Miller MC, Russell T, Sanders RA Jr, et al. Expression of epithelial cell adhesion molecule in carcinoma cells present in blood and primary and metastatic tumors. Int J Oncol. 2005 Jul;27(1): 49-57.

26 Baccelli I, Schneeweiss A, Riethdorf S, Stenzinger A, Schillert A, Vogel V, et al. Identification of a population of blood circulating tumor cells from breast cancer patients that initiates metastasis in a xenograft assay. Nat Biotechnol. 2013 Jun;31(6):539-44.

27 Polioudaki H, Agelaki S, Chiotaki R, Politaki E, Mavroudis D, Matikas A, et al. Variable expression levels of keratin and vimentin reveal differential EMT status of circulating tumor cells and correlation with clinical characteristics and outcome of patients with metastatic breast cancer. BMC Cancer. 2015 May;15(1): 399.

28 Mani SA, Guo W, Liao MJ, Eaton EN, Ayyanan A, Zhou AY, et al. The epithelial-mesenchymal transition generates cells with properties of stem cells. Cell. 2008 May;133(4):70415.

29 Zhang D, Zhao L, Zhou P, Ma H, Huang F, Jin $\mathrm{M}$, et al. Circulating tumor microemboli (CTM) and vimentin+ circulating tumor cells (CTCs) detected by a size-based platform predict worse prognosis in advanced colorectal cancer patients during chemotherapy. Cancer Cell Int. 2017 Jan;17(1):6.

30 Hou JM, Krebs M, Ward T, Sloane R, Priest L, Hughes A, et al. Circulating tumor cells as a window on metastasis biology in lung cancer. Am J Pathol. 2011 Mar;178(3):989-96.
31 Codony-Servat J, Rosell R. Cancer stem cells and immunoresistance: clinical implications and solutions. Transl Lung Cancer Res. 2015 Dec;4(6):689-703.

32 Noman MZ, Messai Y, Muret J, Hasmim M, Chouaib S. Crosstalk between CTC, Immune System and Hypoxic Tumor Microenvironment. Cancer Microenviron. 2014 Dec;7(3): 153-60.

33 Raimondi C, Nicolazzo C, Gradilone A. Circulating tumor cells isolation: the "post-EpCAM era”. Chin J Cancer Res. 2015 Oct;27(5): 461-70.

34 Yokobori $\mathrm{T}$, Iinuma $\mathrm{H}$, Shimamura $\mathrm{T}$, Imoto $\mathrm{S}$, Sugimachi $\mathrm{K}$, Ishii $\mathrm{H}$, et al. Plastin 3 is a novel marker for circulating tumor cells undergoing the epithelial-mesenchymal transition and is associated with colorectal cancer prognosis. Cancer Res. 2013 Apr;73(7):2059-69.

35 Pantel K, Denève E, Nocca D, Coffy A, Vendrell JP, Maudelonde T, et al. Circulating epithelial cells in patients with benign colon diseases. Clin Chem. 2012 May;58(5):936-40.

36 Racila E, Euhus D, Weiss AJ, Rao C, McConnell J, Terstappen LW, et al. Detection and characterization of carcinoma cells in the blood. Proc Natl Acad Sci USA. 1998 Apr; 95(8):4589-94.

37 Cen P, Ni X, Yang J, Graham DY, Li M. Circulating tumor cells in the diagnosis and management of pancreatic cancer. Biochim Biophys Acta. 2012 Dec;1826(2):350-6.

38 Zhang L, Ridgway LD, Wetzel MD, Ngo J, Yin $\mathrm{W}$, Kumar D, et al. The identification and characterization of breast cancer CTCs competent for brain metastasis. Sci Transl Med. 2013 Apr;5(180):180ra48.

39 Joosse SA, Gorges TM, Pantel K. Biology, detection, and clinical implications of circulating tumor cells. EMBO Mol Med. 2015 Jan; $7(1): 1-11$.

40 Foy V, Fernandez-Gutierrez F, Faivre-Finn C, Dive C, Blackhall F. The clinical utility of circulating tumour cells in patients with small cell lung cancer. Transl Lung Cancer Res. 2017 Aug;6(4):409-17.

41 Hou JM, Krebs MG, Lancashire L, Sloane R, Backen A, Swain RK, et al. Clinical significance and molecular characteristics of circulating tumor cells and circulating tumor microemboli in patients with small-cell lung cancer. J Clin Oncol. 2012 Feb;30(5):525-32.

42 Ilie M, Hofman V, Long-Mira E, Selva E, Vignaud JM, Padovani B, et al. "Sentinel” circulating tumor cells allow early diagnosis of lung cancer in patients with chronic obstructive pulmonary disease. PLoS One. 2014 Oct; 9(10):e111597.

43 Hou JM, Greystoke A, Lancashire L, Cummings J, Ward T, Board R, et al. Evaluation of circulating tumor cells and serological cell death biomarkers in small cell lung cancer patients undergoing chemotherapy. Am J Pathol. 2009 Aug;175(2):808-16. 
44 Pore $\mathrm{M}$, Meijer C, de Bock GH, Boersma-van Ek W, Terstappen LW, Groen HJ, et al. Cancer Stem Cells, Epithelial to Mesenchymal Markers, and Circulating Tumor Cells in Small Cell Lung Cancer. Clin Lung Cancer. 2016 Nov; 17(6):535-42.

45 Yu M, Stott S, Toner M, Maheswaran S, Haber DA. Circulating tumor cells: approaches to isolation and characterization. J Cell Biol. 2011 Feb;192(3):373-82.

46 Millner LM, Linder MW, Valdes R Jr. Circulating tumor cells: a review of present methods and the need to identify heterogeneous phenotypes. Ann Clin Lab Sci. 2013;43(3): 295-304.

47 Danila DC, Samoila A, Patel C, Schreiber N, Herkal A, Anand A, et al. Clinical validity of detecting circulating tumor cells by AdnaTest Assay compared with direct detection of tumor mRNA in stabilized whole blood, as a biomarker predicting overall survival for metastatic castration-resistant prostate cancer patients. Cancer J. 2016 Sep/Oct;22(5):31520.

48 Saucedo-Zeni N, Mewes S, Niestroj R, Gasiorowski L, Murawa D, Nowaczyk P, et al. A novel method for the in vivo isolation of circulating tumor cells from peripheral blood of cancer patients using a functionalized and structured medical wire. Int J Oncol. 2012 Oct;41(4):1241-50.

49 Schneck H, Gierke B, Uppenkamp F, Behrens B, Niederacher D, Stoecklein NH, et al. EpCAM-independent enrichment of circulating tumor cells in metastatic breast cancer. PLoS One. 2015 Dec;10(12):e0144535.

50 Imrich S, Hachmeister M, Gires O. EpCAM and its potential role in tumor-initiating cells. Cell Adhes Migr. 2012 Jan-Feb;6(1):30-8.

51 Yang MH, Imrali A, Heeschen C. Circulating cancer stem cells: the importance to select. Chin J Cancer Res. 2015 Oct;27(5):437-49.

52 Satelli A, Batth I, Brownlee Z, Mitra A, Zhou $\mathrm{S}$, Noh $\mathrm{H}$, et al. EMT circulating tumor cells detected by cell-surface vimentin are associated with prostate cancer progression. Oncotarget. 2017 Jul;8(30):49329-37.

53 Blassl C, Kuhlmann JD, Webers A, Wimberger P, Fehm T, Neubauer H. Gene expression profiling of single circulating tumor cells in ovarian cancer - Establishment of a multimarker gene panel. Mol Oncol. 2016 Aug; 10(7):1030-42.

54 Alix-Panabières C, Vendrell JP, Pellé O, Rebillard X, Riethdorf S, Müller V, et al. Detection and characterization of putative metastatic precursor cells in cancer patients. Clin Chem. 2007 Mar;53(3):537-9.

55 Somlo G, Lau SK, Frankel P, Hsieh HB, Liu X, Yang L, et al. Multiple biomarker expression on circulating tumor cells in comparison to tumor tissues from primary and metastatic sites in patients with locally advanced/inflammatory, and stage IV breast cancer, using a novel detection technology. Breast Cancer Res Treat. 2011 Jul;128(1):155-63.
56 Ntouroupi TG, Ashraf SQ, McGregor SB, Turney BW, Seppo A, Kim Y, et al. Detection of circulating tumour cells in peripheral blood with an automated scanning fluorescence microscope. Br J Cancer. 2008 Sep;99(5):789-95.

57 Pantel K, Brakenhoff RH, Brandt B. Detection, clinical relevance and specific biological properties of disseminating tumour cells. Nat Rev Cancer. 2008 May;8(5):329-40.

58 Lianidou ES, Markou A. Circulating tumor cells in breast cancer: detection systems, molecular characterization, and future challenges. Clin Chem. 2011 Sep;57(9):1242-55.

59 Harouaka RA, Nisic M, Zheng SY. Circulating tumor cell enrichment based on physical properties. J Lab Autom. 2013 Dec;18(6): 455-68.

60 Alix-Panabières C. EPISPOT assay: detection of viable DTCs/CTCs in solid tumor patients. Recent Results Cancer Res. 2012;195:69-76.

61 Fuchs AB, Romani A, Freida D, Medoro G, Abonnenc M, Altomare L, et al. Electronic sorting and recovery of single live cells from microlitre sized samples. Lab Chip. 2006 Jan; 6(1):121-6.

62 Peeters DJ, De Laere B, Van den Eynden GG, Van Laere SJ, Rothé F, Ignatiadis $\mathrm{M}$, et al. Semiautomated isolation and molecular characterisation of single or highly purified tumour cells from CellSearch enriched blood samples using dielectrophoretic cell sorting. Br J Cancer. 2013 Apr;108(6):1358-67.

63 Paolillo C, Mu Z, Rossi G, Schiewer MJ, Nguyen T, Austin L, et al. Detection of Activating Estrogen Receptor Gene (ESR1) Mutations in Single Circulating Tumor Cells. Clin Cancer Res. 2017 Oct;23(20):6086-93.

64 Fischer AH. Circulating tumor cells: seeing is believing. Arch Pathol Lab Med. 2009 Sep; 133(9):1367-9.

65 Vona G, Sabile A, Louha M, Sitruk V, Romana $\mathrm{S}$, Schütze $\mathrm{K}$, et al. Isolation by size of epithelial tumor cells : a new method for the immunomorphological and molecular characterization of circulatingtumor cells. Am J Pathol. 2000 Jan;156(1):57-63

66 Hofman V, Bonnetaud C, Ilie MI, Vielh P, Vignaud JM, Fléjou JF, et al. Preoperative circulating tumor cell detection using the isolation by size of epithelial tumor cell method for patients with lung cancer is a new prognostic biomarker. Clin Cancer Res. 2011 Feb;17(4): $827-35$.

67 Lowe AC, Pignon JC, Carvo I, Drage MG, Constantine NM, Jones N, et al. Young investigator challenge: Application of cytologic techniques to circulating tumor cell specimens: Detecting activation of the oncogenic transcription factor STAT3. Cancer Cytopathol. 2015 Dec;123(12):696-706.

68 Pesta M, Kulda V, Narsanska A, Fichtl J, Topolcan O. May CTC technologies promote better cancer management? EPMA J. 2015 Jan;6(1):1.
69 Gerlinger M, Rowan AJ, Horswell S, Math M, Larkin J, Endesfelder D, et al. Intratumor heterogeneity and branched evolution revealed by multiregion sequencing. $\mathrm{N}$ Engl J Med. 2012 Mar;366(10):883-92.

70 Almendro V, Fuster G. Heterogeneity of breast cancer: etiology and clinical relevance. Clin Transl Oncol. 2011 Nov;13(11):767-73.

71 Camara O, Rengsberger M, Egbe A, Koch A, Gajda M, Hammer U, et al. The relevance of circulating epithelial tumor cells (CETC) for therapy monitoring during neoadjuvant (primary systemic) chemotherapy in breast cancer. Ann Oncol. 2007 Sep;18(9):1484-92.

72 Rüdiger N, Stein EL, Schill E, Spitz G, Rabenstein C, Stauch M, et al. Chemosensitivity testing of circulating epithelial tumor cells (CETC) in vitro: correlation to in vivo sensitivity and clinical outcome. $J$ Cancer Ther. 2013;4(2):597-605

73 Gallant JN, Matthew EM, Cheng H, Harouaka R, Lamparella NE, Kunkel M, et al. Predicting therapy response in live tumor cells isolated with the flexible micro spring array device. Cell Cycle. 2013 Jul;12(13):2132-43.

74 Yu M, Bardia A, Aceto N, Bersani F, Madden MW, Donaldson MC, et al. Cancer therapy. Ex vivo culture of circulating breast tumor cells for individualized testing of drug susceptibility. Science. 2014 Jul;345(6193):216-20.

75 Grillet F, Bayet E, Villeronce O, et al. Circulating tumour cells from patients with colorectal cancer have cancer stem cell hallmarks in ex vivo culture. Gut. 2017 Oct;66(10):1802-10.

76 Toss A, Mu Z, Fernandez S, Cristofanilli M. CTC enumeration and characterization: moving toward personalized medicine. Ann Transl Med. 2014 Nov;2(11):108.

77 Stebbing J, Payne R, Reise J, Frampton AE, Avery M, Woodley L, et al. The efficacy of lapatinib in metastatic breast cancer with HER2 non-amplified primary tumors and EGFR positive circulating tumor cells: a proof-of-concept study. PLoS One. 2013 May; 8(5):e62543.

78 Bidard FC, Fehm T, Ignatiadis M, Smerage JB, Alix-Panabières C, Janni W, et al. Clinical application of circulating tumor cells in breast cancer: overview of the current interventional trials. Cancer Metastasis Rev. 2013 Jun;32(12): $179-88$

79 Zhang Y, Zhang X, Zhang J, Sun B, Zheng L, $\mathrm{Li}$ J, et al. Microfluidic chip for isolation of viable circulating tumor cells of hepatocellular carcinoma for their culture and drug sensitivity assay. Cancer Biol Ther. 2016 Nov; 17(11): 1177-87.

80 Hughes AD, Marshall JR, Keller E, Powderly JD, Greene BT, King MR. Differential drug responses of circulating tumor cells within patient blood. Cancer Lett. 2014 Sep;352(1): $28-35$.

81 Cristofanilli M, Budd GT, Ellis MJ, Stopeck A, Matera J, Miller MC, et al. Circulating tumor cells, disease progression, and survival in metastatic breast cancer. N Engl J Med. 2004 Aug; 351(8):781-91. 
82 Abbott A. Cell culture: biology's new dimension. Nature. 2003 Aug;424(6951):870-2.

83 Smalley KS, Lioni M, Herlyn M. Life isn't flat: taking cancer biology to the next dimension. In Vitro Cell Dev Biol Anim. 2006 Sep-Oct; 42(8-9):242-7.

84 Weigelt B, Bissell MJ. Unraveling the microenvironmental influences on the normal mammary gland and breast cancer. Semin Cancer Biol. 2008 Oct;18(5):311-21.

$85 \mathrm{Xu} \mathrm{F}$, Burg KJ. Three-dimensional polymeric systems for cancer cell studies. Cytotechnology. 2007 Jul;54(3):135-43.

86 Page H, Flood P, Reynaud EG. Three-dimensional tissue cultures: current trends and beyond. Cell Tissue Res. 2013 Apr;352(1):12331.

87 Breslin S, O’Driscoll L. Three-dimensional cell culture: the missing link in drug discovery. Drug Discov Today. 2013 Mar;18(5-6) 240-9.

88 Yamada KM, Cukierman E. Modeling tissue morphogenesis and cancer in 3D. Cell. 2007 Aug;130(4):601-10.

89 Valyi-Nagy K, Voros A, Gagyi E, Valyi-Nagy $\mathrm{T}$. Increased resistance of vasculogenic mimicry-forming uveal melanoma cells against cytotoxic agents in three-dimensional cultures. Cult Tech. 2011;18:377-92.

90 Mueller-Klieser W, Freyer JP, Sutherland RM. Influence of glucose and oxygen supply conditions on the oxygenation of multicellular spheroids. Br J Cancer. 1986 Mar;53(3): $345-53$.

91 Frieboes HB, Zheng X, Sun CH, Tromberg B, Gatenby R, Cristini V. An integrated computational/experimental model of tumor invasion. Cancer Res. 2006 Feb;66(3):1597-604.

92 Dawson E, Mapili G, Erickson K, Taqvi S, Roy K. Biomaterials for stem cell differentiation. Adv Drug Deliv Rev. 2008 Jan;60(2):215-28.

93 Tibbitt MW, Anseth KS. Hydrogels as extracellular matrix mimics for $3 \mathrm{D}$ cell culture. Biotechnol Bioeng. 2009 Jul;103(4):655-63.

94 Gurski LA, Petrelli NJ, Jia X, Farach-Carson MC. 3D matrices for anti-cancer drug testing and development. Oncol Issues. 2010;25(1): 20-5.

95 Valent P, Bonnet D, De Maria R, Lapidot T, Copland M, Melo JV, et al. Cancer stem cell definitions and terminology: the devil is in the details. Nat Rev Cancer. 2012 Nov;12(11): 767-75.

96 Bichsel CA, Gobaa S, Kobel S, Secondini C, Thalmann GN, Cecchini MG, et al. Diagnostic microchip to assay 3D colony-growth potential of captured circulating tumor cells. Lab Chip. 2012 Jul;12(13):2313-6.

97 Stakenborg T, Liu C, Henry O, Borgen E, Laddach N, Roeser T, et al. Automated genotyping of circulating tumor cells. Expert Rev Mol Diagn. 2010 Sep;10(6):723-9.
98 Hirschhaeuser F, Menne H, Dittfeld C, West J, Mueller-Klieser W, Kunz-Schughart LA. Multicellular tumor spheroids: an underestimated tool is catching up again. J Biotechnol. 2010 Jul;148(1):3-15.

99 Friedrich J, Seidel C, Ebner R, KunzSchughart LA. Spheroid-based drug screen: considerations and practical approach. Nat Protoc. 2009;4(3):309-24.

100 Härmä V, Virtanen J, Mäkelä R, Happonen A, Mpindi JP, Knuuttila M, et al. A comprehensive panel of three-dimensional models for studies of prostate cancer growth, invasion and drug responses. PLoS One. 2010 May;5(5):e10431.

101 Ross AA, Cooper BW, Lazarus HM, Mackay W, Moss TJ, Ciobanu N, et al. Detection and viability of tumor cells in peripheral blood stem cell collections from breast cancer patients using immunocytochemical and clonogenic assay techniques. Blood. 1993 Nov; 82(9):2605-10

102 Theodoropoulos PA, Polioudaki H, Agelaki S, Kallergi G, Saridaki Z, Mavroudis D, et al. Circulating tumor cells with a putative stem cell phenotype in peripheral blood of patients with breast cancer. Cancer Lett. 2010 Feb;288(1):99-106.

103 Ma J, Lin JY, Alloo A, Wilson BJ, Schatton $\mathrm{T}$, Zhan $\mathrm{Q}$, et al. Isolation of tumorigenic circulating melanoma cells. Biochem Biophys Res Commun. 2010 Nov;402(4):711-

104 Kasimir-Bauer S, Hoffmann O, Wallwiener D, Kimmig R, Fehm T. Expression of stem cell and epithelial-mesenchymal transition markers in primary breast cancer patients with circulating tumor cells. Breast Cancer Res. 2012 Jan;14(1):R15.

105 Economos C, Morrissey C, Vessella RL. Circulating tumor cells as a marker of response: implications for determining treatment efficacy and evaluating new agents. Curr Opin Urol. 2012 May;22(3):190-6.

106 Zhang Z, Shiratsuchi H, Lin J, Chen G, Reddy RM, Azizi E, et al. Expansion of CTCs from early stage lung cancer patients using a microfluidic co-culture model. Oncotarget. 2014 Dec;5(23):12383-97.

107 Kang JH, Krause S, Tobin H, Mammoto A, Kanapathipillai M, Ingber DE. A combined micromagnetic-microfluidic device for rapid capture and culture of rare circulating tumor cells. Lab Chip. 2012 Jun;12(12):217581.

108 Infanger DW, Lynch ME, Fischbach C. Engineered culture models for studies of tumor-microenvironment interactions. Annu Rev Biomed Eng. 2013;15(1):29-53.

109 Zhu C, Yago T, Lou J, Zarnitsyna VI, McEver RP. Mechanisms for flow-enhanced cell adhesion. Ann Biomed Eng. 2008 Apr; 36(4):604-21.

110 Chang KC, Hammer DA. The forward rate of binding of surface-tethered reactants: effect of relative motion between two surfaces. Biophys J. 1999 Mar;76(3):1280-92.
111 Lim YC, Garcia-Cardena G, Allport JR, Zervoglos M, Connolly AJ, Gimbrone MA Jr, et al. Heterogeneity of endothelial cells from different organ sites in T-cell subset recruitment. Am J Pathol. 2003 May;162(5):1591601.

112 Hida K, Hida Y, Amin DN, Flint AF, Panigrahy $\mathrm{D}$, Morton CC, et al. Tumor-associated endothelial cells with cytogenetic abnormalities. Cancer Res. 2004 Nov;64(22): 8249-55.

113 Gao D, Vela I, Sboner A, Iaquinta PJ, Karthaus WR, Gopalan A, et al. Organoid cultures derived from patients with advanced prostate cancer. Cell. 2014 Sep;159(1):17687.

114 Sachs N, Clevers H. Organoid cultures for the analysis of cancer phenotypes. Curr Opin Genet Dev. 2014 Feb;24:68-73.

115 Broutier L, Andersson-Rolf A, Hindley CJ, Boj SF, Clevers H, Koo BK, et al. Culture and establishment of self-renewing human and mouse adult liver and pancreas 3D organoids and their genetic manipulation. Nat Protoc. 2016 Sep;11(9):1724-43.

116 Pizon M, Schott D, Pachmann U, Pachmann $\mathrm{K}$. The number of tumorspheres cultured from peripheral blood is a predictor for presence of metastasis in patients with breast cancer. Oncotarget. 2016 Jul;7(30): 48143-54.; Epub ahead of print.

117 Barriere G, Fici P, Gallerani G, Fabbri F, Zoli W, Rigaud M. Circulating tumor cells and epithelial, mesenchymal and stemness markers: characterization of cell subpopulations. Ann Transl Med. 2014 Nov;2(11):109.

118 Li J, Shi L, Zhang X, Sun B, Yang Y, Ge N, et al. pERK/pAkt phenotyping in circulating tumor cells as a biomarker for sorafenib efficacy in patients with advanced hepatocellular carcinoma. Oncotarget. 2016 Jan;7(3): 2646-59.

119 Lovitt CJ, Shelper TB, Avery VM. Miniaturized three-dimensional cancer model for drug evaluation. Assay Drug Dev Technol. 2013 Sep;11(7):435-48.

120 Pantel K, Alix-Panabières C. Cell lines from circulating tumor cells. Oncoscience. 2015 Aug;2(10):815-6

121 Kulasinghe A, Perry C, Warkiani ME, Blick T, Davies A, O'Byrne K, et al. Short term exvivo expansion of circulating head and neck tumour cells. Oncotarget. 2016 Sep;7(37): 60101-9.; Epub ahead of print.

122 Mishra DK, Scott KL, Wardwell-Ozgo JM, Thrall MJ, Kim MP. Circulating tumor cells from 4D model have less integrin beta 4 expression. J Surg Res. 2015 Feb;193(2):74553.

123 Ravi M, Paramesh V, Kaviya SR, Anuradha E, Solomon FD. 3D cell culture systems: advantages and applications. J Cell Physiol. 2015 Jan;230(1):16-26. 